\title{
Enhanced LH action in transgenic female mice expressing hCG $\beta$-subunit induces pituitary prolactinomas; the role of high progesterone levels
}

\author{
Petteri Ahtiainen ${ }^{1,2}$, Victoria Sharp ${ }^{3}$, Susana B Rulli, ${ }^{1,4}$, Adolfo Rivero-Müller ${ }^{1}$, \\ Veronika Mamaeva' ${ }^{1}$, Matias Röyttä5 and llpo Huhtaniemi ${ }^{1,3}$
}

\begin{abstract}
${ }^{1}$ Department of Physiology and ${ }^{2}$ Turku Graduate School of Biomedical Science, University of Turku, FIN-20520 Turku, Finland ${ }^{3}$ Department of Surgery and Cancer, Imperial College London, Hammersmith Campus, Du Cane Road, London W12 0NN, UK ${ }^{4}$ Institute of Biology and Experimental Medicine-CONICET, Vuelta de Obligado 2490, Buenos Aires 1428, Argentina

${ }^{5}$ Department of Pathology, University of Turku, FIN-20520 Turku, Finland
\end{abstract}

(Correspondence should be addressed to I Huhtaniemi at Department of Surgery and Cancer, Imperial College London, London W12 ONN, UK; Email: ilpo.huhtaniemi@imperial.ac.uk)

\begin{abstract}
The etiology of pituitary adenomas remains largely unknown, with the exception of involvement of estrogens in the formation of prolactinomas. We have examined the molecular pathogenesis of prolactin-producing pituitary adenomas in transgenic female mice expressing the human choriongonadotropin (hCG) $\beta$-subunit. The LH/CG bioactivity is elevated in the mice, with consequent highly stimulated ovarian progesterone $\left(\mathrm{P}_{4}\right)$ production, in the face of normal estrogen secretion. Curiously, despite normal estrogen levels, large prolactinomas developed in these mice, and we provide here several lines of evidence that the elevated $\mathrm{P}_{4}$ levels are involved in the growth of these estrogen-dependent tumors. The antiprogestin mifepristone inhibited tumor growth, and combined postgonadectomy estradiol/ $/ \mathrm{P}_{4}$ treatment was more effective than estrogen alone in inducing tumor growth. Evidence for direct growth-promoting effect of $\mathrm{P}_{4}$ was obtained from cultures of primary mouse pituitary cells and rat somatomammotroph $\mathrm{GH} 3$ cells. The mouse tumors and cultured cells revealed stimulation of the cyclin D1/cyclin-dependent kinase 4/retinoblastoma protein/transcription factor E2F1 pathway in the growth response to $P_{4}$. If extrapolated to humans, and given the importance of endogenous $\mathrm{P}_{4}$ and synthetic progestins in female reproductive functions and their pharmacotherapy, it is relevant to revisit the potential role of these hormones in the origin and growth of prolactinomas.
\end{abstract}

Endocrine-Related Cancer (2010) 17 611-621

\section{Introduction}

The prevalence of pituitary adenomas is according to a recent report 94/100 000 (Daly et al. 2006), and prolactinomas are by far the commonest form of pituitary tumors $(66 \%)$. The incidence of microadenomas in autopsy materials is even higher, $23-27 \%$, and almost $50 \%$ of them stain positively for prolactin (PRL; McComb et al. 1983). Female sex is a risk factor for prolactinomas in humans, apparently due to the effects of estradiol $\left(\mathrm{E}_{2}\right)$. This link is supported for example by more common occurrence of these tumors in women (Faglia 1993, Drange et al. 2000), the increase of their growth during pregnancy (Molitch 1999), the stimulating effect of estrogens on PRL secretion (Lieberman et al. 1981, Maurer 1982), and the occurrence of lactotroph adenomas in transsexual men during pharmacological estrogen treatment (Mueller \& Gooren 2008). Likewise, several rodent models support the role of estrogens in the formation of prolactinomas (Walker \& Kurth 1993, Heaney et al. 2002, Hentges \& Low 2002). Estrogens are 
apparently not the only cause, and the role of other possible ovarian hormones and local growth factors in this tumorigenesis is less well defined. Although progesterone $\left(\mathrm{P}_{4}\right)$ receptors are expressed in mouse pituitary lactotroph cells (Turgeon et al. 2001) and human prolactinomas (Jaffrain-Rea et al. 1996), the role of $\mathrm{P}_{4}$ in pituitary tumorigenesis remains confusing with reports on both stimulatory and inhibitory effects in rodents (Poel 1966, Lamberts et al. 1985).

Recent studies have elucidated the molecular pathogenesis of pituitary adenomas. Increased activation of the cyclin D1 (CCND1)/cyclin-dependent kinase 4 (CDK4)/retinoblastoma protein (RB)/ transcription factor E2F1 pathway, or its suppressed inhibition due to deficiency of $p 18$ and $p 27$, has been shown to play an important role in mouse models of pituitary tumors (Jacks et al. 1992, Franklin et al. 1998, Yamasaki et al. 1998). In humans, tissue-specific overexpression of $C C N D 1$, or decreased expression of $p 16, p 18$, and $p 27$, is common in tumors of the pituitary gland (Peters 1994, Musat et al. 2004). Recently, overexpression of the high-mobility group protein A2 (HMGA2) in pituitary tumors has been described in mice and men (Fedele et al. 2006). This factor binds to the inactive $\mathrm{RB} / \mathrm{E} 2 \mathrm{~F} 1$ complex, displacing histone deacetylase 1 (HDAC1), leading to histone acetylation, opening of the chromatin structure, and stabilizing E2F1 (Fedele et al. 2006).

Besides the role of $E_{2}$ in the pathogenesis of pituitary tumors (Heaney et al. 2002), $\mathrm{E}_{2}$-induced proliferation in breast cancer cells activates c-fos, c-jun, and c-myc (Sutherland et al. 1998, Cicatiello et al. 2004), and in endometrial carcinoma extracellularsignal-related kinase (ERK)1/2 (Kashima et al. 2009), leading in both models to upregulation of cyclins D1 and E. Synergism between $\mathrm{E}_{2}$ and $\mathrm{P}_{4}$ action has been observed in some endocrine tumors. In cultured post-menopausal, hormonally treated breast tissue, $\mathrm{E}_{2}$, the synthetic progestin medroxyprogesterone acetate and their combination increase the number of Ki-67-positive cells (Eigeliene et al. 2008), with concomitant increase in CCND1 and p21-positive cells and reduced $\mathrm{p} 27$ expression. Whether similar synergism is possible between $\mathrm{E}_{2}$ and $\mathrm{P}_{4}$ in the pathogenesis of pituitary adenomas has not been studied.

We have reported previously that transgenic (TG) female mice with elevated LH/human choriongonadotropin (hCG) action through the expression of the hCG $\beta$-subunit develop lactotroph adenomas in early adult life, in the face of only a short temporary peripubertal increase in ovarian $\mathrm{E}_{2}$ production, but persistently high $\mathrm{P}_{4}$ levels (Rulli et al. 2002). In the current study, we explore in more detail the role of the high circulating levels of $\mathrm{P}_{4}$ in these animals in the growth of the pituitary adenomas and elucidate the molecular mechanisms involved.

\section{Materials and methods}

\section{The transgenic mouse model}

TG female mice of the FVB/N strain expressing heterozygously the $h C G \beta$-subunit cDNA, driven by the human ubiquitin $\mathrm{C}$ promoter, and their genotyping and housing have been described before (Rulli et al. 2002). Non-TG littermates were used as controls. The animals were handled, and the experiments were approved in accordance with the local institutional animal care policies.

\section{Treatments, and blood and tissue collections}

In the hormone antagonist study, wild-type (WT) and TG female mice were subjected to sham operation (C) or gonadectomy (Gx) at 2 months of age, and thereafter treated with various combinations of tamoxifen (Sigma-Aldrich Co.), mifepristone (Sigma-Aldrich), and bromocriptine (IRA, Sarasota, FL, USA), as described in Table 1. In the hormone treatment study, WT and TG females were sham operated or gonadectomized at 2 months of age, and thereafter treated up to 4.5 months of age with $\mathrm{E}_{2}$ and/or $\mathrm{P}_{4}$, as described in Table 1.

Following treatments, the mice were killed by cervical dislocation between 0800 and $1100 \mathrm{~h}$. Blood was collected by cardiac puncture, and serum was separated by centrifugation and stored at $-70{ }^{\circ} \mathrm{C}$ until analyzed. Pituitary glands were weighed, fixed in $4 \%$ paraformaldehyde or snap-frozen in liquid nitrogen, and stored at $-70{ }^{\circ} \mathrm{C}$ until needed.

\section{Hormone measurements}

PRL was measured by RIA as described previously (Bergendahl et al. 1989).

\section{Histological analysis and immunohistochemistry}

Paraformaldehyde-fixed pituitaries were cut into $10 \mu \mathrm{m}$ sections and stained with Harris' hematoxylin-eosin. Immunohistochemistry was carried out with standard techniques, using commercial monoclonal antibodies against mouse Ki-67, and human CCND1, CDK4, and RB; the sources, dilutions, and protocols used are described in Supplementary data. 
Table 1 The treatment schemes with hormone antagonists and hormones

\begin{tabular}{llll}
\hline Treatment & Abbreviation & Gonadectomy (age) & Treatment period \\
\hline Antagonist treatments & $\mathrm{C}$ & - & - \\
Control (no treatment) & $\mathrm{Br}$ & - & $2-6$ months \\
Bromocriptine & $\mathrm{Mf}$ & - & $2-6$ months \\
Mifepristone & $\mathrm{Tx}$ & - & $2-6$ months \\
Tamoxifen & $\mathrm{MfTx}$ & - & $2-6$ months \\
Mifepristone+tamoxifen & $\mathrm{STx}$ & - & 7 days-2 months \\
Short tamoxifen & $\mathrm{STxMf}$ & - & 7 days-2 months (Tx) \\
Short tamoxifen+mifepristone & $\mathrm{Gx}$ & 2 months & $2-6$ months (Mf) \\
Gonadectomy & $\mathrm{C}$ & 2 months & $2-4.5$ months \\
Hormone treatments & $\mathrm{Gx}+\mathrm{E}_{2}$ & 2 months & $2-4.5$ months \\
Control (no treatment) & $\mathrm{Gx}+\mathrm{P}_{4}$ & 2 months & $2-4.5$ months \\
Gx+estradiol & $\mathrm{Gx}+\mathrm{E}_{2} / \mathrm{P}_{4}$ & 2 months & $2-4.5$ months \\
Gx+progesterone & $\mathrm{Gx}$ & & \\
\hline
\end{tabular}

Tx was administered as a $1 \mathrm{~cm}$ long subcutaneous silastic tubes, and progesterone and mifepristone were administered as $2 \mathrm{~cm}$ long subcutaneous silastic tubes (inner diameter $1.58 \mathrm{~mm} /$ outer diameter $2.41 \mathrm{~mm}$; Dow Corning, Midland, MI, USA) with both ends sealed with silastic adhesive (Elastocil RTV-1 Silicone Rubber, Wacker-Chemis GmBH, Munich, Germany). Bromocriptine and estradiol were administered as commercial subcutaneous pellets, and changed every 80-90 days after the initial implantation. Progesterone was administered in a $1 \mathrm{~cm}$ subcutaneous silastic tube. The mice in the short tamoxifen and tamoxifen + mifepristone experiments received tamoxifen by daily injections ( $10 \mathrm{mg} / \mathrm{kg}$ body weight s.c.) between 7 and 21 days, thereafter by silastic tubes until 2 months. All mice were killed at the end of the treatment periods.

\section{Assessment of cell proliferation}

The density of proliferating cells (DPCs) was calculated by counting the Ki-67-positive nuclei and adjusting the result for the measurement area $\left(\mathrm{mm}^{2}\right)$, using the Leica IM 1000, version 1.02 software (Leica Microsystems AG, Heerbrugg, Switzerland). At least three samples per group and two sections per sample were analyzed. From the 12-month-old TG pituitaries showing macroscopic nodules, proliferation index (PI) was calculated as the percentage of Ki-67-positive cells in the nodular area. To this end, samples were counterstained by hematoxylin, and ten fields at $40 \times$ magnification were calculated per nodule. The DPC from the same nodules was also determined.

\section{Quantitative RT-PCR}

Total pituitary RNA was extracted by the RNeasy mini kit (Qiagen) according to the manufacturer's instructions. Prior to quantitative RT-PCR (qRT-PCR), all samples were treated with deoxyribonuclease I (Invitrogen). Expression levels were determined for genes presented in Supplementary Table 1, see section on supplementary data given at the end of this article (including the primer pairs, annealing temperatures, and gene bank accession numbers). qRT-PCR analysis was carried out as described previously (Ahtiainen et al. 2005). Further details about the methodology and quality control are presented in Supplementary data.

\section{Primary cell cultures}

Primary pituitary cell cultures were performed as described earlier, with minor modifications (Pastorcic et al. 1995). Briefly, 3-5 pituitary glands of 5-month-old female hCG $\beta$-TG mice were enzymatically dissociated in PBS containing $1 \mathrm{~g} / \mathrm{l}$ D-glucose, $2 \mathrm{~g} / \mathrm{l}$ collagenase, $1 \mathrm{~g} / \mathrm{l}$ BSA (SigmaAldrich), and $200 \mu \mathrm{M}$ ascorbic acid (Merck) and $60 \times 10^{3} \mathrm{U} / 1$ DNase 1 (Epicentre, Madison, WI, USA) for $40 \mathrm{~min}$ in a shaker at $37^{\circ} \mathrm{C}$, followed by trituration to disperse the fragments. Cells were plated in Growth Factor Reduced Matrigel matrix (BD Biosciences, Bedford, MI, USA)-coated 24-well plates in DMEM/F12 medium containing penicillin $\left(50 \times 10^{3} \mathrm{U} / \mathrm{l}\right)$ and streptomycin $(50 \mathrm{mg} / \mathrm{l}$; SigmaAldrich), $200 \mu \mathrm{M}$ ascorbic acid, $1 \mathrm{~g} / \mathrm{l} \mathrm{BSA}$, and $10 \%$ FCS for $24 \mathrm{~h}$. The cells were washed with PBS and incubated for $24 \mathrm{~h}$ in DMEM/F12 medium containing the antibiotics and 5\% dextran-coated charcoal-treated FCS in the presence of $\mathrm{E}_{2}, \mathrm{P}_{4}$, or both. RNA was collected immediately after the experiments (RNeasy mini kit).

\section{Culture of GH3 cells}

GH3 cells were cultured in high glucose DMEM growth medium (Sigma-Aldrich) supplemented with $10 \%$ FCS and $1 \%$ penicillin/streptomycin (Invitrogen). 
Cells were maintained in a 96-well plate $\left(10^{4}\right.$ cells/well) in growth medium for $8 \mathrm{~h}$, and then cultured overnight using medium supplemented with $2 \%$ dextran-coated charcoal-stripped FBS and $1 \%$ penicillin/streptomycin.

For the determination of cell proliferation, treatments were performed for $48 \mathrm{~h}$ in $2 \%$ dextran-coated charcoal-stripped serum containing medium. Control cells were treated with vehicle alone, which never exceeded the final concentration of $0.01 \%$ ( $\mathrm{vol} / \mathrm{vol})$. The steroids were dissolved in either ethanol $\left(\mathrm{E}_{2}\right.$ and $\mathrm{P}_{4}$ ) or dimethyl sulfoxide (mifepristone and dexamethasone (Sigma-Aldrich)) to a concentration of $1 \mathrm{mM}$, and further diluted in medium to the required concentrations. At the end of the treatment, the CellTiter 96 Aqueous One Solution Cell Proliferation Assay (Promega) was performed by adding $20 \mu \mathrm{l}$ of the 3-(4,5-dimethylthiazol-2-yl)-5-(3-carboxymethonylphenol)-2-(4-sulphenyl)-2H-tetrazolium salt to each well. The induced color change was measured using a standard 96-well plate reader at $490 \mathrm{~nm}$. In parallel wells, cells were counted by the trypan blue exclusion method.

\section{Statistical analysis}

Statistical analyses were performed using the SigmaStat 3.1 software (SPSS Inc., Chicago, IL, USA) or the SAS System software version 9.1.3 SP2 (SAS Institute, Gary, NC, USA). One-way ANOVA was used for multiple comparisons followed by Holm-Sidak's or Dunn's post-hoc tests. Student's t-test was used to analyze differences between two groups. Friedman test, followed by Dunn's multiple comparison test, was used to analyze the results of the cell culture experiments. Statistical analyses of pituitary weights and PRL levels in the hormone ablation and replacement experiments were performed by two-way ANOVA and analysis of covariance. Natural logtransformation was used when necessary. Residual was checked for justification of the analyses. For correlation analyses, Pearson product moment correlation was used. For the GH3 cell proliferation experiments, all statistical tests were performed using GraphPad Prism 4 statistical software, version 4.01 (GraphPad Inc., San Diego, CA, USA). Cell proliferation was compared between treatments using two-way ANOVA and within treatment using one-way ANOVA, followed by the post-hoc Bonferroni multiple comparison test, where appropriate. All results are presented as mean \pm s.E.M. A $P$ value $<0.05$ was considered statistically significant.

\section{Results}

\section{Female hCG $\beta$-TG mice develop after puberty large prolactinomas with high DPCs}

As shown before (Rulli et al. 2002), the female TG mice develop gradually after puberty large multinodular pituitary adenomas, up to $150 \mathrm{mg}$ in weight, and giving rise to high serum PRL levels, up to a mean of $10 \mathrm{mg} / \mathrm{l}$ (Supplementary Figure 1, see section on supplementary data given at the end of this article). At the age of 10-12 months, all TG females have macroprolactinomas. PRL was the only anterior pituitary hormone detected by immunohistochemistry in the tumorous tissue (Supplementary Figure 2, see section on supplementary data given at the end of this article). The distribution of Ki-67-positive cells (Fig. 1) in the pituitary glands indicated a change from diffuse hyperplasia at 4 months of age to focal adenomatous growth at 6 months of age, and an increase with age in the density and proportion (PI; not shown) of proliferating cells with age (Fig. 1). At 12 months of age, large nodules of macroprolactinomas were seen with numerous Ki-67-positive cells. The DPCs in the macroadenomas was higher than in the rest of the pituitary gland. No metastasis or local invasion was observed, indicating that the tumors were not malignant.

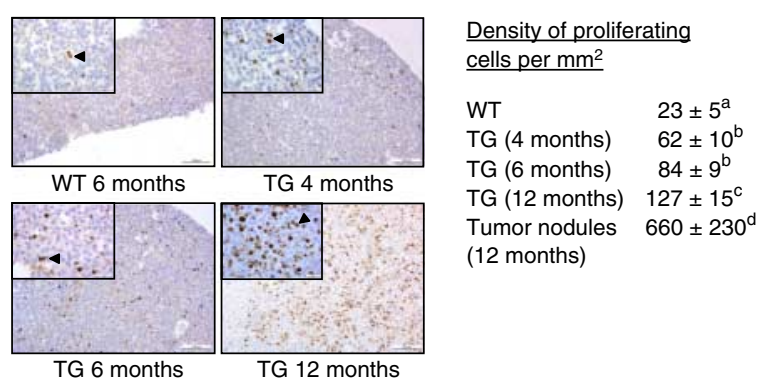

Figure 1 Immunohistochemical evaluation of Ki-67 expression and density of proliferating cells in the pituitary glands of wild-type (WT) and transgenic (TG) female mice. Representative immunohistochemical images of Ki-67 staining are shown in 6-month-old WT, and 4-, 6-, and 12-month-old TG mouse samples. The arrowheads indicate Ki-67-positive cells. A large part of the 12-month-old TG sample comprises a macroprolactinoma with numerous Ki-67-positive cells. Scale bars are $100 \mu \mathrm{m}$, and the insets are larger magnifications of the same samples (scale bar $=25 \mu \mathrm{m}$ ). Numeric data on density of proliferating cells $/ \mathrm{mm}^{2}$ in the pituitary glands are presented on the right side. The WT values are the mean of the 4-, 6-, and 12 -month-old mice. Different superscript letters indicate that these groups differ significantly $(P<0.05)$; three to seven mice were analyzed per group (mean \pm S.E.M.), and at least two sections were calculated per specimen. Full colour version of this figure available via http://dx.doi.org/10.1677/ERC-10-0016. 


\section{Hormonal manipulations reveal the importance of elevated $\mathrm{P}_{4}$ level in the pituitary tumorigenesis}

To evaluate the influence of ovarian hormones on pituitary growth and PRL levels, WT and TG mice were first subjected to hormone antagonist treatments (Fig. 2A and B) as described in Table 1. The pituitary weights and serum PRL levels of WT animals did not show significant responses to any of the antagonist treatments. Gx of TG mice at 2 months of age completely abolished both the pituitary growth and increase in PRL levels observed in intact TG mice
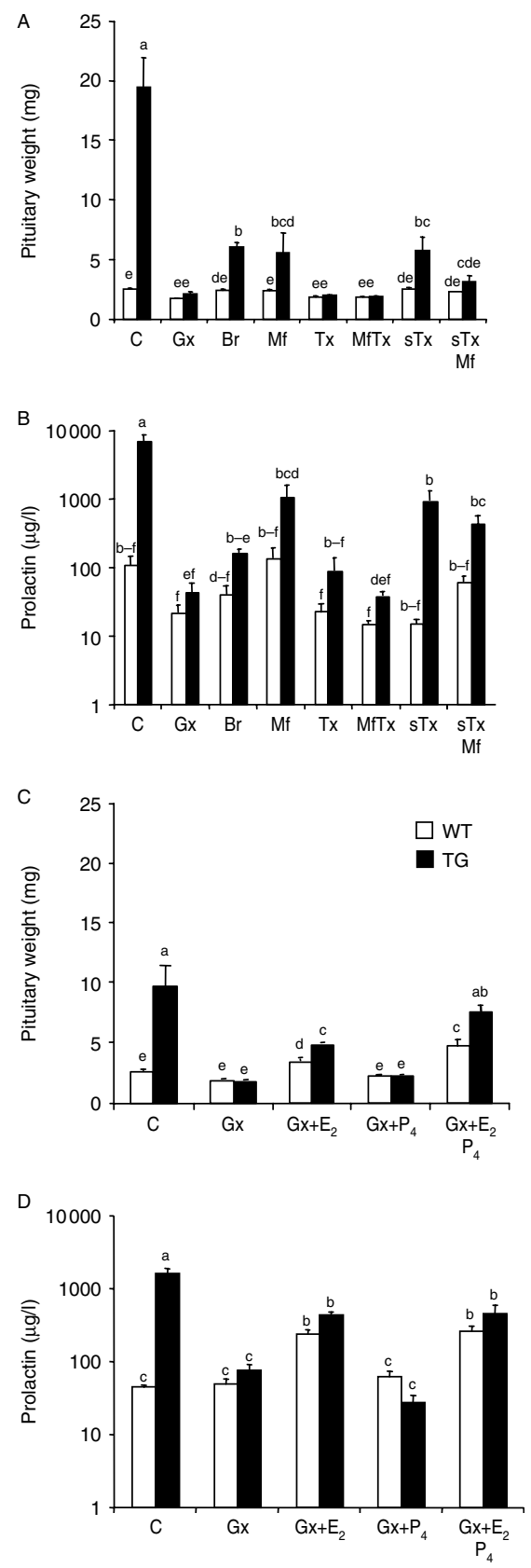

at 6 months of age. The inhibitory effects of tamoxifen and tamoxifen + mifepristone combination were equal. Somewhat weaker inhibition was found with bromocriptine and mifepristone alone. Short tamoxifen treatment between 1 week and 2 months of age, to block the action of the peripubertal $\mathrm{E}_{2}$ peak in $\mathrm{TG}$ females (Rulli et al. 2002), persistently reduced pituitary weights, and subsequent mifepristone treatment of these mice (2-6 months) showed a trend of a further decrease $(P=0.08)$.

The hormone replacement study (Table 1 and Fig. 2C and D) was shorter (2-4.5 months), and therefore, the differences between WT and TG mice were smaller than upon hormone ablation. $E_{2}$ treatment increased pituitary weights of Gx WT and TG mice, but not to the size observed in intact $\mathrm{TG}$ females. $\mathrm{P}_{4}$ alone was without effect, but $\mathrm{E}_{2}+\mathrm{P}_{4}$ combination returned the weights in Gx TG mice to levels similar to intact TG mice. Interestingly, $\mathrm{P}_{4}$ had no effect on PRL secretion either alone or in combination with $\mathrm{E}_{2}$. This fact, and the finding that $\mathrm{P}_{4}$ receptor ( $\left.P g r\right)$ expression was increased by $\mathrm{E}_{2}$, but not by $\mathrm{P}_{4}$ (Supplementary Figure $3 \mathrm{D}$, see section on supplementary data given at the end of this article), indicated that the $\mathrm{P}_{4}$ effect on pituitary growth was not due to its conversion to $\mathrm{E}_{2}$.

\section{Ccnd1/Cdk4, E2f1, and Hmga2 are up-regulated, and RB1 is down-regulated, in the adenomatous pituitaries}

A number of candidate genes with putative involvement in the pituitary adenoma formation, selected on the basis of literature, were studied by qRT-PCR for altered expression in the tumors (Supplementary Table 1). Because intact ovaries were necessary for

Figure 2 Pituitary weights and serum PRL concentrations in the WT and TG mice, and their responses to hormonal manipulations in the antagonist treatment (A and $\mathrm{B})$ and hormone treatment $(C$ and $D)$ experiments, as explained in Table 1. Pituitary weights ( $A$ and $C$ ) and serum PRL levels ( $B$ and $D)$ of WT control (open bars) and TG (filled bars) mice were measured (mean \pm s.E.M.; 5-16 mice/group). In A and B, the data are obtained from 6-month-old mice gonadectomized (Gx) or sham-operated (C) at 2 months of age, followed by treatment between 2 and 6 months of age with bromocriptine $(\mathrm{Br})$, mifepristone (Mf), tamoxifen (Tx), or Mf $+\mathrm{Tx}$ combination. In addition, one group of mice received short Tx treatment between 2 weeks and 2 months (sTx; to abolish the peripubertal $\mathrm{E}_{2}$ peak), and in one group, the latter was followed by a 2-6-month-treatment with Mf (sTxMf). In C and D, the data are obtained from 4.5-month-old mice with $\mathrm{Gx}$ at 2 months of age, followed by 2.5-month treatments with vehicle $(\mathrm{Gx}), \mathrm{E}_{2}(\mathrm{Gx}+$ $\left.E_{2}\right), P_{4}\left(G x+P_{4}\right)$, or their combination $\left(G x+E_{2} P_{4}\right)$. For marking of statistical differences, each bar is provided by superscript letters. If all letters between two bars are different (e.g. ab and cd), then they differ significantly at $P<0.05$. If any of the superscript letters of two bars is the same (e.g. ab and bc), then there is no statistically significant difference between them. 
the development of prolactinomas (Rulli et al. 2002), genes responsive to ovarian hormones $\left(\mathrm{E}_{2}\right.$ and/or $\left.\mathrm{P}_{4}\right)$, and/or involved in cell proliferation and/or tumor promotion, were selected for the screening performed on samples from 6-month-old WT and TG mice. The genes with increased expression in TG mice were subjected to more detailed analysis.
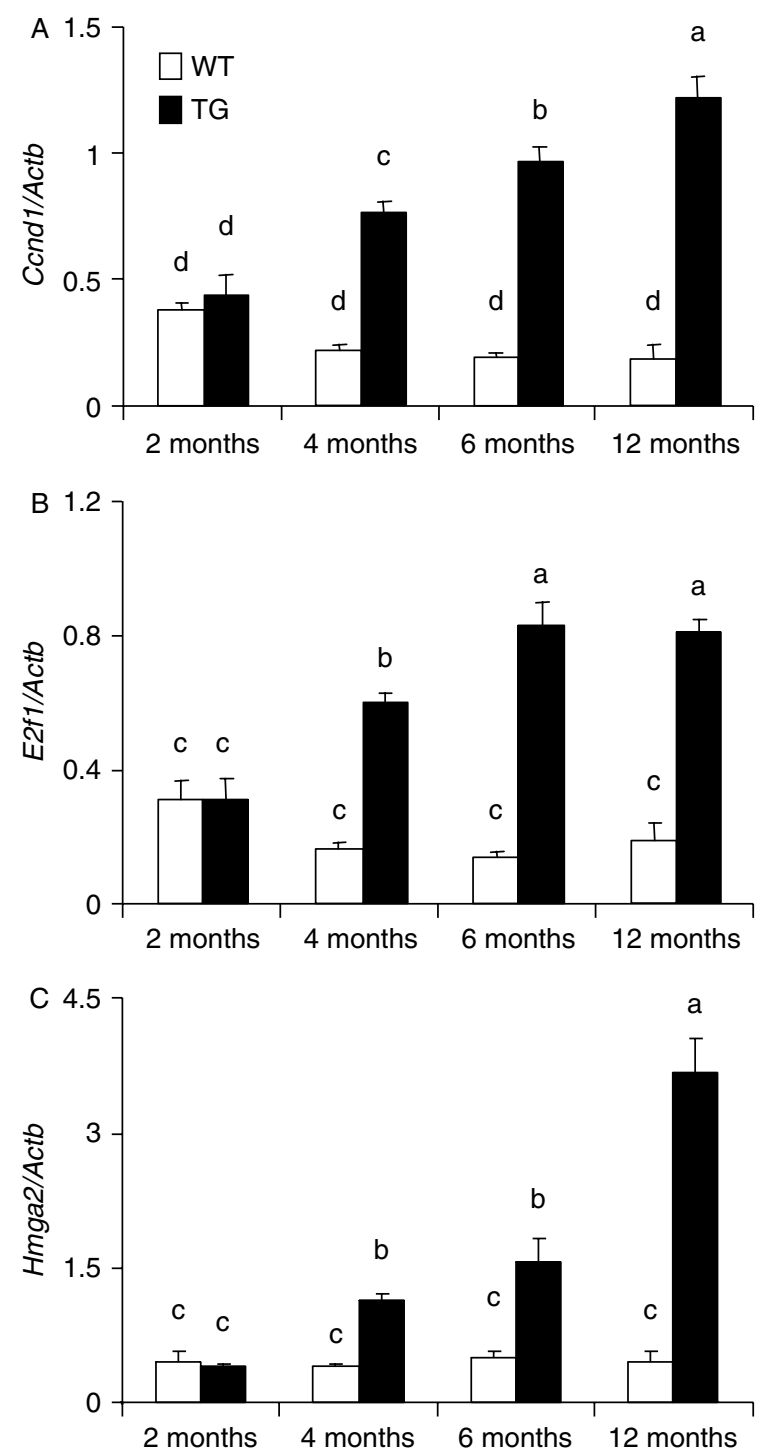

D WT 4 months TG 4 months TG 6 months TG 12 months

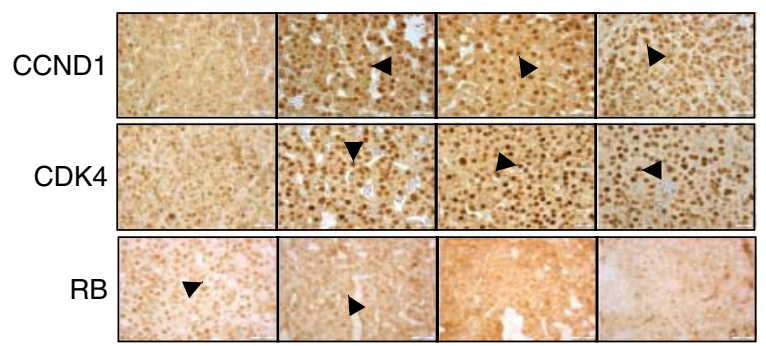

One of the candidate genes, Ccndl, showed gradually increased expression with advancing age of the TG mice, up to 6.1-fold at 12 months of age (Fig. 3A), in line with the concomitant increases in DPC (Fig. 1) and pituitary weight (Supplementary Figure 1). Pituitary E2fl expression reached its maximum in TG mice at 6 months of age (Fig. 3B), in good agreement with $C c n d l$ expression $(r=0.95)$. Hmga2 expression also gradually increased in the TG pituitaries (Fig. 3C).

The CCND1 and CDK4 responses were confirmed by immunohistochemistry (Fig. 3D). In WT pituitaries, nuclear CCND1 immunoreactivity was present in sporadic cells, whereas in 4-6-month-old TG samples, most cells were prominently stained, and at 12 months, practically all pituitary cell nuclei were positive. The intensity of the nuclear staining for CDK4, the partner of CCND1, followed the same pattern (Fig. 3D). As an indicator of activity of the CCND1/ CDK4 complex, the immunostaining of the downstream effector RB showed an expected reciprocal decline. At 12 months, most TG pituitary cells were RB negative, whereas almost all WT cells presented with positive nuclear RB staining.

The other genes with clearly elevated expression (greater than threefold) in the pituitary tumors, but not studied in further detail, included Pttg1, Fgf2, Nuprl, and Paqr5 (Supplementary Table 1).

\section{Response of pituitary gene expression to hormone manipulations}

We then analyzed the responses of selected genes, with likely involvement in the tumorigenesis, to $\mathrm{Gx}$ and hormone antagonist treatments (Table 1); the results are presented in Fig. 4. Gx and all antihormone treatments reduced the expression of Ccndl and E2fl. The expression of Hmga2, a stabilizer of E2F1 (Fedele et al. 2006), was suppressed by Gx and mifepristone, but not by bromocriptine. $P g r$ expression was measured because of the putative involvement of $\mathrm{P}_{4}$

Figure 3 Pituitary expression of Ccnd1, E2f1, Hmga2, CDK4, and RB in WT and TG female mice. (A-C) depict the levels of Ccnd1, E2fi, and Hmga2 respectively as measured by qRT-

PCR, in WT (open bars) and TG (filled bars) mice at 2, 4, 6, and 12 months of age (mean \pm S.E.M. of $4-6$ mice/group). Bars with different superscript letters differ significantly $(P<0.05)$.

(D) Shows representative micrographs of CCND1, CDK4, and RB immunohistochemistry of WT and TG mice at the ages (mo) indicated. The arrows indicate nuclei positive for the respective stainings. Note the weak nuclear staining of CCND1 and CDK4 in WT mice. Similar expression patterns were observed with CCND1 and CDK4. The bottom row of panels presents RB expression, which shows strong nuclear staining in WT but weak in TG mice, especially in older ages. The scale bars are $25 \mu \mathrm{m}$ in the insets. Full colour version of this figure available via http://dx.doi.org/10.1677/ERC-10-0016. 

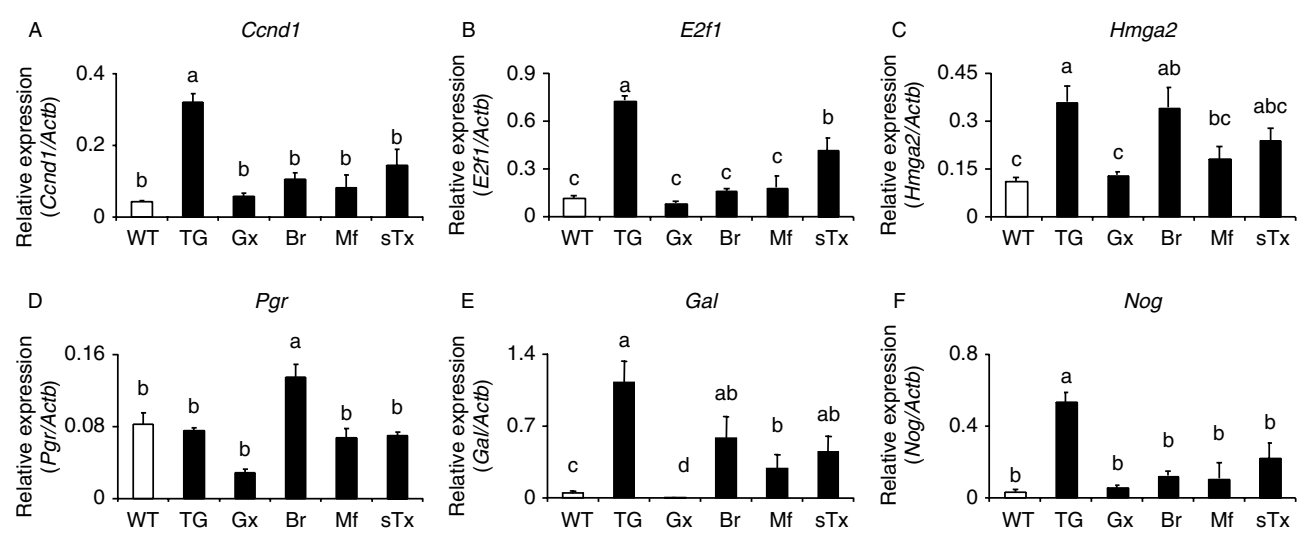

Figure 4 Pituitary expression levels of selected genes in WT and TG mice, and their responses to hormonal manipulations. The genes studied were Ccnd1 (A), E2f1 (B), Hmga2 (C), Pgr (D), Gal (E), and Nog (F). For treatments and abbreviations, see Table 1, antagonist treatments. The results shown are mean \pm s.E.M. of 3-5 mice per group. Bars with different superscript letters differ significantly $(P<0.05)$.

in the tumorigenesis. Its expression did not differ between the WT and TG females, but was decreased by Gx and slightly increased by bromocriptine. Galanin is a marker of lactotrophs and their response to estrogens (Hyde et al. 1991), and its expression was highly up-regulated in the TG pituitaries, and dramatically suppressed by Gx, while the other hormone manipulations had smaller decreasing effects. Because of the only slight 2.1-fold overexpression of bone morphogenic protein 4 (Bmp4), a known stimulus of prolactinoma growth (Paez-Pereda et al. 2003), in the TG pituitaries, we also assessed the expression level of noggin (Nog), the inhibitor of BMP4 (Supplementary Table 1). Its expression was highly elevated in the TG pituitaries, excluding BMP4 as a likely stimulus of the pituitary tumorigenesis. In the hormone manipulation experiments, the levels of Nog and Gal expression correlated closely with the pituitary tumor size (not shown). The short-term treatment with tamoxifen was somewhat less effective than the other antagonist treatments.

Additional data on serum $\mathrm{P}_{4}$ levels, uterine weights, Pgr mRNA expression, and pituitary ESR1 and PGR immunohistochemistry are presented in Supplementary Figure 3. Responses of the anterior pituitary hormones (at mRNA level) to the hormonal manipulations are presented in Supplementary Figure 4, see section on supplementary data given at the end of this article.

\section{Effect of $E_{2}, P_{4}$, and their combination on primary mouse pituitary cells and GH3 cells}

Finally, to obtain further evidence for a direct $\mathrm{P}_{4}$ effect on pituitary cell proliferation, we stimulated primary pituitary cells of adult TG females with $E_{2}$, $\mathrm{P}_{4}$, and their combination. The concentrations used
$\left(\mathrm{E}_{2}=100 \mathrm{pmol} / \mathrm{l}\right.$ and $\left.\mathrm{P}_{4}=100 \mathrm{nmol} / \mathrm{l}\right)$ were similar to those measured in TG female serum (Rulli et al. 2002). Only the $\mathrm{E}_{2}+\mathrm{P}_{4}$ combination, but not either hormone alone, induced significant upregulation of Ccndl expression (Fig. 5A).

We then treated rat somatomammotroph GH3 cells with $\mathrm{E}_{2}, \mathrm{P}_{4}$, and their combinations. When cultured in the presence of a submaximally stimulating concentration of $\mathrm{E}_{2}(100 \mathrm{pM}), 0.1$ and $1 \mathrm{nM} \mathrm{P} \mathrm{P}_{4}$ significantly enhanced cell proliferation (Fig. 5B). $\mathrm{P}_{4}$ alone had no effect up to $1000 \mathrm{nM}$ (Supplementary Figure 6A, see section on supplementary data given at the end of this article); neither did it enhance the proliferation effect of the maximally stimulating $\mathrm{E}_{2}$ concentration of $1 \mathrm{nM}$. Mifepristone significantly reduced the effect of $\mathrm{E}_{2}+\mathrm{P}_{4}$ on cell proliferation, further supporting the contributory role of $\mathrm{P}_{4}$ in the presence of physiological $\mathrm{E}_{2}$ levels. When $\mathrm{P}_{4}$ was replaced by dexamethasone, no additive effect on the cell proliferation stimulated by $\mathrm{E}_{2}$ was seen (Supplementary Figure 5B, see section on supplementary data given at the end of this article), indicating that the $\mathrm{P}_{4}$ effect was unlikely due to the activation of the glucocorticoid receptor. Moreover, both Esrl, Esr2, and $\operatorname{Pgr}$ (a and b isoforms) messages (Supplementary Figure 5D) and PGR protein (Supplementary Figure 5E) were expressed in the GH3 cells, but neither CYP17 nor CYP19 (Supplementary Figure 5D). Hence, the $\mathrm{P}_{4}$ effect can be mediated in GH3 cells through the cognate nuclear receptor, but not through its conversion to $\mathrm{E}_{2}$. Finally, phosphorylated forms of ERK and RB proteins were detected in the GH3 cells by western blots (Supplementary Figure 5E), indicating that the same signaling mechanisms as in the pituitary tumors respond to $\mathrm{E}_{2} / \mathrm{P}_{4}$ stimulation in the $\mathrm{GH} 3$ cells. 

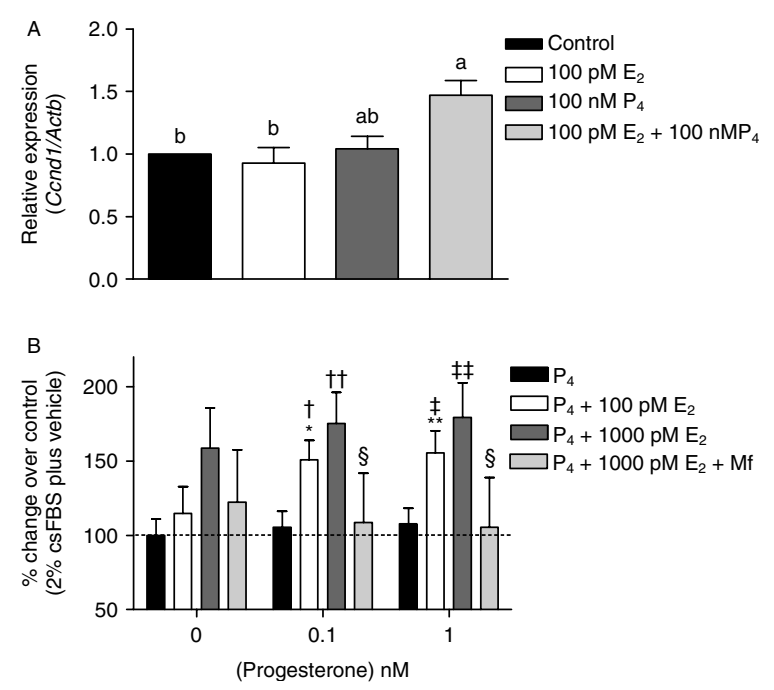

Figure 5 Effects of $E_{2}, P_{4}$, and their combinations on cell proliferation and signaling in primary mouse pituitary cells and rat somatomammotroph GH3 cells. (A) Expression of Ccnd1 mRNA in primary pituitary cells isolated from 5-month-old TG mice and stimulated for $24 \mathrm{~h}$ as indicated. The results are mean \pm S.E.M. of five individual experiments. Different letters indicate significant differences $(P<0.05)$ between the treatment groups. (B) Effects of $48 \mathrm{~h} \mathrm{P}_{4}$ stimulation on $\mathrm{GH} 3$ cell proliferation when co-treated with $E_{2}$ and/or mifepristone (Mf). The mean cell number in controls was taken as $100 \%$, and those of the other treatments were related to this figure (mean \pm S.E.M. of 5-6 independent experiments). ${ }^{*} P<0.05$, ${ }^{\star \star} P<0.01$ versus basal plus $100 \mathrm{pM} \mathrm{E} \mathrm{E}_{2} ;{ }^{\dagger} P<0.05,{ }^{\dagger \dagger} P<0.01$ vs $0.1 \mathrm{nM} \mathrm{P}_{4} ;{ }^{\ddagger} P<0.05$, ${ }^{\ddagger \ddagger} P<0.01$ vs $1 \mathrm{nM} \mathrm{P}_{4} ;{ }^{\S} P<0.01$ vs 0.1 and $1 \mathrm{nM} \mathrm{P}_{4}+1000 \mathrm{pM} \mathrm{E}_{2}+10 \mu \mathrm{M}$ Mf.

\section{Discussion}

We observed in this study that the growth of estrogendependent pituitary adenomas in hCG expressing TG mice is amplified by $\mathrm{P}_{4}$. This finding was supported by $\mathrm{P}_{4}$ effects in cultured primary mouse pituitary cells and in a rat somatomammotroph cell line. The mechanism of the tumor promotion in the presence of $\mathrm{P}_{4}$ was found to involve in the activation of CCND1 and HMGA2, which are also activated in human pituitary adenomas (Peters 1994, Fedele et al. 2006). Hence, the molecular pathogenesis of these murine tumors may have similar features with that of human pituitary adenomas.

In deciphering the mechanism of the tumorpromoting effect of high $\mathrm{P}_{4}$ level in the TG mice, it is important to exclude the possibility that the effect of $\mathrm{P}_{4}$ is indirect through pituitary or extrapituitary conversion of $\mathrm{P}_{4}$ to $\mathrm{E}_{2}$, a well-established stimulus of pituitary adenomas. Several of our findings support a direct $\mathrm{P}_{4}$ effect. First, the experiments with GH3 cells, not able to convert $\mathrm{P}_{4}$ to $\mathrm{E}_{2}$, showed the amplifying effect of $\mathrm{P}_{4}$ on $\mathrm{E}_{2}$-stimulated cell proliferation. Secondly, treatment with the $\mathrm{P}_{4}$ (and glucocorticoid) antagonist mifepristone clearly inhibited the pituitary growth. Thirdly, in $\mathrm{Gx}$ mice, $\mathrm{E}_{2}+\mathrm{P}_{4}$ combination was more effective in inducing pituitary growth than $E_{2}$ alone. Fourthly, $\mathrm{P}_{4}$ alone had no effect on pituitary growth, and showed no estrogenic effects, such as stimulation of PRL secretion or upregulation of pituitary $P g r$ expression, thus excluding the conversion of $\mathrm{P}_{4}$ to functionally meaningful levels of $\mathrm{E}_{2}$.

The role of $E_{2}$ in the induction of pituitary adenomas is well known (Heaney et al. 2002), but that of the other ovarian sex hormone, $\mathrm{P}_{4}$, remains controversial. While several previous studies demonstrate the inhibitory effects of $\mathrm{P}_{4}$ on the growth and PRL production of normal and tumorous pituitary cells (Haug \& Gautvik 1976, Piroli et al. 2001, Rey-Roldan et al. 2008), there are also studies on stimulatory effects of this steroid, especially in combination with $\mathrm{E}_{2}$ (Poel 1966, Chen \& Meites 1970, Williams et al. 1994, Yen \& Pan 1998). In contrast, ample evidence shows stimulatory effect of $\mathrm{P}_{4}$, and $\mathrm{P}_{4} / \mathrm{E}_{2}$ combination, on the growth other hormone-responsive tumors, such as breast and uterine carcinomas (Cicatiello et al. 2004, Saitoh et al. 2005). The effect observed is intimately dependent on the cell type, timing and dose of treatment, and the effect of $\mathrm{P}_{4}$ is often biphasic, with an acute stimulatory effect followed by loss of the effect or inhibition. The stimulatory $\mathrm{P}_{4}$ effect may only occur in the presence of physiological $\mathrm{E}_{2}$ levels, but not on its own, or when the $\mathrm{E}_{2}$ level is supraphysiological.

Additive and synergistic effects of $\mathrm{E}_{2}$ and $\mathrm{P}_{4}$ are well known on the growth of other hormone-responsive tumors. In the mammary gland and uterine epithelium, $\mathrm{E}_{2}$ clearly stimulates cell proliferation, whereas $\mathrm{P}_{4}$ has both stimulatory and inhibitory effects (Sutherland et al. 1998). In contrast, in uterine stroma, $\mathrm{P}_{4}$ stimulates cell proliferation both in the presence and in the absence of $\mathrm{E}_{2}$ (Martin et al. 1973). The mitogenic effect of $\mathrm{E}_{2}$ and $\mathrm{P}_{4}$ in breast cancer cells is mediated through increased CCND1-Cdk4 activity (Sutherland et al. 1998, Cicatiello et al. 2004, Saitoh et al. 2005). Both hormones apparently share the same cascade, but because $\mathrm{E}_{2}$ upregulates $P g r$ expression, $\mathrm{E}_{2}$ priming in fact enhances the $\mathrm{P}_{4}$ response.

Mutations, locally produced growth factors and hypothalamic endocrine dysregulation, have been shown to be involved in the pathogenesis of pituitary adenomas. In our mouse model, the hCG-stimulated ovarian steroidogenesis apparently provides a mitotic stimulus to the pituitary gland. Indeed, we found out that $\mathrm{P}_{4}$ up-regulated in the TG mice, when exposed to physiological levels of $E_{2}$, the well-established tumorigenic CCND1/CDK4/RB/E2F1 signaling cascade. The same effect of $\mathrm{P}_{4}$ was observed in cultures of primary mouse pituitary and rat GH3 cells. 
Concomitant upregulation of the architectural transcription factor Hmga2 was found in the pituitary adenoma, in keeping with its established involvement in pituitary tumorigenesis in mice and men (Fedele et al. 2006). Hence, CCND1 activation, leading to stimulation of E2F1 expression, seems to occur by several converging mechanisms in our pituitary adenomas model. One is decreased RB expression, which results in E2F1 activation, the other is upregulation of HMGA2, which displaces HDAC1 from the inactive $\mathrm{pRB} / \mathrm{E} 2 \mathrm{~F} 1$ complex, resulting in the acetylation and activation of the latter (Fedele et al. 2006). In addition, we found in GH3 cells increased RB phosphorylation, which results in inactivation of this protein and enhanced cyclin $\mathrm{D}$ stimulation of E2F1.

CCND1 is a known target of the MAPK/ERK signaling pathway, and continued Ccndl expression requires sustained MAPK activation (Lavoie et al. 1996). Cross-talk between ESR1 and PGR has shown to be mediated through the SRC/P21ras/ERK pathway in human breast cancer cells (Migliaccio et al. 1998). Dopamine D2 receptors mediate their inhibitory signaling through inactivation of ERK1/2 (Liu et al. 2002), explaining why bromocriptine treatment down-regulated Ccndl. Tamoxifen, bromocriptine, and mifepristone treatments also down-regulated Ccndl expression, suggesting that the upregulation of pituitary Ccndl expression in TG females could occur through cross-talk between normal $\mathrm{E}_{2}$ and high $\mathrm{P}_{4}$ levels, and decreased dopaminergic tone. Similar responses were observed with the downstream effector E2f1, in agreement with a recent report that CCND1 can recruit its own promoter through the $\mathrm{RB} / \mathrm{E} 2 \mathrm{~F}$ pathway after ESR1/PGR activation (Cicatiello et al. 2004). The role of $P_{4}$ was further confirmed in cultured primary pituitary cells showing that only the $\mathrm{E}_{2} / \mathrm{P}_{4}$ combination induced Ccndl expression. This finding indicates the importance of cross-talk between $\mathrm{E}_{2}$ and $\mathrm{P}_{4}$ also in the pituitary gland. Further evidence for the direct $\mathrm{P}_{4}$ action on pituitary cell proliferation, in the presence of physiological $\mathrm{E}_{2}$ concentration, was provided by the GH3 cell culture, in connection with $\mathrm{RB}$ inactivation and ERK activation, both through $\mathrm{P}_{4}$-stimulated phosphorylation.

A potential weakness of this study is the physiological relevance of the highly elevated hormonal responses evoked by hCG $\beta$ expression in these animals. This in particular concerns the high $\mathrm{P}_{4}$ levels, about $200 \mathrm{nmol} / \mathrm{l} \mathrm{vs}<10 \mathrm{nmol} / \mathrm{l}$ in WT controls, at the time of onset of tumor growth (19), which are about an order of magnitude higher than in human luteal phase. Assuming that the tumorigenic $\mathrm{P}_{4}$ effect is dose-dependent, the macroprolactinomas in the TG mice represent responses to a high dose. Smaller, but still significant, tumorigenic effects of $\mathrm{P}_{4}$ are likely to occur at lower levels that are more relevant to human physiology. Our results provide a hypothesis for testing the efficacy of mifepristone as an adjuvant in the treatment of bromocriptine resistant prolactinomas.

In conclusion, we have demonstrated an amplifying effect of $\mathrm{P}_{4}$ on the growth of $\mathrm{E}_{2}$-induced pituitary tumors in female TG mice exposed to high levels of bioactive $\mathrm{LH} / \mathrm{hCG}$. It appears that in the presence of normal $\mathrm{E}_{2}$ levels, the CCND1/CDK4/RB/E2F1 pathway can be directly enhanced by $\mathrm{P}_{4}$, with concomitant activation of several oncogenes, including $H m g a 2$ and E2fl, and downregulation/inactivation of RB. Taken the importance of $\mathrm{P}_{4}$ in all reproductive functions of the female, and as a component of numerous medications (including contraceptive and hormone replacement therapy regimens), it may be important to address its potential role in the formation and treatment of pituitary adenomas.

\section{Supplementary data}

This is linked to the online version of the paper at http://dx. doi.org/10.1677/ERC-10-0016.

\section{Declaration of interest}

The authors declare that there is no conflict of interest that could be perceived as prejudicing the impartiality of the research reported.

\section{Funding}

This study was supported by grants from The Academy of Finland (Centre of Excellence Grant No. 211480), The Sigrid Jusélius Foundation, The Finnish Cancer Foundation, The Turku Graduate School for Biomedical Sciences, and The Wellcome Trust (Programme Grants 063552 and 082101).

\section{Author contribution statement}

$\mathrm{P}$ Ahtiainen designed the experiments, performed the in vivo experiments, analyzed the data, and wrote the maniscript; V Sharp performed the cell culture experiments; S B Rulli participated in the in vivo experiments; A Rivero-Müller participated in the analysis of the biological samples; $\mathrm{V}$ Mamaeva participated in the in vivo experiments; $\mathrm{M}$ Röyttä participated in the analysis of the histological samples; I Huhtaniemi participated in the design of the experiment, analysis of the data, and writing of the manuscript. 


\section{Acknowledgements}

We wish to acknowledge Dr R C Fowkes of the Royal Veterinary College (London, UK) for the kind gift of $\mathrm{GH} 3$ cells.

\section{References}

Ahtiainen P, Rulli SB, Shariatmadari R, Pelliniemi LJ, Toppari J, Poutanen M \& Huhtaniemi IT 2005 Fetal but not adult Leydig cells are susceptible to adenoma formation in response to persistently high hCG level: a study on hCG overexpressing transgenic mice. Oncogene 24 7301-7309.

Bergendahl M, Perheentupa A \& Huhtaniemi I 1989 Effect of short-term starvation on reproductive hormone gene expression, secretion and receptor levels in male rats. Journal of Endocrinology 121 409-417.

Chen CL \& Meites J 1970 Effects of estrogen and progesterone on serum and pituitary prolactin levels in ovariectomized rats. Endocrinology 86 503-505.

Cicatiello L, Addeo R, Sasso A, Altucci L, Petrizzi VB, Borgo R, Cancemi M, Caporali S, Caristi S, Scafoglio C et al. 2004 Estrogens and progesterone promote persistent CCND1 gene activation during G1 by inducing transcriptional derepression via c-Jun/c-Fos/estrogen receptor (progesterone receptor) complex assembly to a distal regulatory element and recruitment of cyclin D1 to its own gene promoter. Molecular and Cellular Biology $\mathbf{2 4}$ 7260-7274.

Daly AF, Rixhon M, Adam C, Dempegioti A, Tichomirowa MA \& Beckers A 2006 High prevalence of pituitary adenomas: a cross-sectional study in the province of Liege, Belgium. Journal of Clinical Endocrinology and Metabolism 91 4769-4775.

Drange MR, Fram NR, Herman-Bonert V \& Melmed S 2000 Pituitary tumor registry: a novel clinical resource. Journal of Clinical Endocrinology and Metabolism $\mathbf{8 5}$ 168-174.

Eigeliene N, Harkonen P \& Erkkola R 2008 Effects of estradiol and medroxyprogesterone acetate on expression of the cell cycle proteins cyclin D1, p21 and p27 in cultured human breast tissues. Cell Cycle 7 71-80.

Faglia G 1993 Epidemiology and pathogenesis of pituitary adenomas. Acta Endocrinologica 129 1-5.

Fedele M, Visone R, De Martino I, Troncone G, Palmieri D, Battista S, Ciarmiello A, Pallante P, Arra C, Melillo RM et al. 2006 HMGA2 induces pituitary tumorigenesis by enhancing E2F1 activity. Cancer Cell 9 459-471.

Franklin DS, Godfrey VL, Lee H, Kovalev GI, Schoonhoven R, Chen-Kiang S, Su L \& Xiong Y 1998 CDK inhibitors p18(INK4c) and p27(Kip1) mediate two separate pathways to collaboratively suppress pituitary tumorigenesis. Genes and Development 12 2899-2911.

Haug E \& Gautvik KM 1976 Effects of sex steroids on prolactin secreting rat pituitary cells in culture. Endocrinology 99 1482-1489.
Heaney AP, Fernando M \& Melmed S 2002 Functional role of estrogen in pituitary tumor pathogenesis. Journal of Clinical Investigation 109 277-283.

Hentges ST \& Low MJ 2002 Ovarian dependence for pituitary tumorigenesis in D2 dopamine receptor-deficient mice. Endocrinology 143 4536-4543.

Hyde JF, Engle MG \& Maley BE 1991 Colocalization of galanin and prolactin within secretory granules of anterior pituitary cells in estrogen-treated Fischer 344 rats. Endocrinology 129 270-276.

Jacks T, Fazeli A, Schmitt EM, Bronson RT, Goodell MA \& Weinberg RA 1992 Effects of an Rb mutation in the mouse. Nature 359 295-300.

Jaffrain-Rea ML, Petrangeli E, Ortolani F, Fraioli B, Lise A, Esposito V, Spagnoli LG, Tamburrano G, Frati L \& Gulino A 1996 Cellular receptors for sex steroids in human pituitary adenomas. Journal of Endocrinology 151 175-184.

Kashima H, Shiozawa T, Miyamoto T, Suzuki A, Uchikawa J, Kurai M \& Konishi I 2009 Autocrine stimulation of IGF1 in estrogen-induced growth of endometrial carcinoma cells: involvement of the mitogen-activated protein kinase pathway followed by up-regulation of cyclin D1 and cyclin E. Endocrine-Related Cancer16 113-122.

Lamberts SW, Uitterlinden P, Bons EG \& Verleun T 1985 Comparison of the actions of RU 38486 and megestrol acetate in the model of a transplantable adrenocorticotropin- and prolactin-secreting rat pituitary tumor. Cancer Research 45 1015-1019.

Lavoie JN, L'Allemain G, Brunet A, Muller R \& Pouyssegur $\mathrm{J} 1996$ Cyclin D1 expression is regulated positively by the p42/p44MAPK and negatively by the p38/HOGMAPK pathway. Journal of Biological Chemistry 271 20608-20616.

Lieberman ME, Maurer RA, Claude P, Wiklund J, Wertz N \& Gorski J 1981 Regulation of pituitary growth and prolactin gene expression by estrogen. Advances in Experimental Medicine and Biology 138 151-163.

Liu JC, Baker RE, Sun C, Sundmark VC \& Elsholtz HP 2002 Activation of $\mathrm{G}_{\mathrm{o}}$-coupled dopamine D2 receptors inhibits ERK1/ERK2 in pituitary cells. A key step in the transcriptional suppression of the prolactin gene. Journal of Biological Chemistry 277 35819-35825.

Martin L, Hallowes RC, Finn CA \& West DG 1973 Involvement of the uterine blood vessels in the refractory state of the uterine stroma which follows oestrogen stimulation in progesterone-treated mice. Journal of Endocrinology 56 309-314.

Maurer RA 1982 Estradiol regulates the transcription of the prolactin gene. Journal of Biological Chemistry 257 2133-2136.

McComb DJ, Ryan N, Horvath E \& Kovacs K 1983 Subclinical adenomas of the human pituitary. New light on old problems. Archives of Pathology \& Laboratory Medicine 107 488-491. 
Migliaccio A, Piccolo D, Castoria G, Di Domenico M, Bilancio A, Lombardi M, Gong W, Beato M \& Auricchio F 1998 Activation of the Src/p21ras/Erk pathway by progesterone receptor via cross-talk with estrogen receptor. EMBO Journal 17 2008-2018.

Molitch ME 1999 Management of prolactinomas during pregnancy. Journal of Reproductive Medicine 44 1121-1126.

Mueller A \& Gooren L 2008 Hormone-related tumors in transsexuals receiving treatment with cross-sex hormones. European Journal of Endocrinology 159 197-202.

Musat M, Vax VV, Borboli N, Gueorguiev M, Bonner S, Korbonits M \& Grossman AB 2004 Cell cycle dysregulation in pituitary oncogenesis. Frontiers of Hormone Research 32 34-62.

Paez-Pereda M, Giacomini D, Refojo D, Nagashima AC, Hopfner U, Grubler Y, Chervin A, Goldberg V, Goya R, Hentges ST et al. 2003 Involvement of bone morphogenetic protein 4 (BMP-4) in pituitary prolactinoma pathogenesis through a Smad/estrogen receptor crosstalk. PNAS 100 1034-1039.

Pastorcic M, De A, Boyadjieva N, Vale W \& Sarkar DK 1995 Reduction in the expression and action of transforming growth factor beta 1 on lactotropes during estrogeninduced tumorigenesis in the anterior pituitary. Cancer Research 55 4892-4898.

Peters G 1994 The D-type cyclins and their role in tumorigenesis. Journal of Cell Science. Supplement 18 89-96.

Piroli GG, Cassataro J, Pietranera L, Grillo CA, Ferrini M, Lux-Lantos V \& De Nicola AF 2001 Progestin regulation of galanin and prolactin gene expression in oestrogen-induced pituitary tumours. Journal of Neuroendocrinology 13 302-309.

Poel WE 1966 Pituitary tumors in mice after prolonged feeding of synthetic progestins. Science $154402-403$.

Rey-Roldan EB, Grillo CA, Pietranera L, Libertun C, Nicola AF \& Piroli GG 2008 Levonorgestrel antagonism on estrogeninduced pituitary tumors is mediated by progesterone receptors. Hormone and Metabolic Research 40 245-250.
Rulli SB, Kuorelahti A, Karaer O, Pelliniemi LJ, Poutanen M \& Huhtaniemi I 2002 Reproductive disturbances, pituitary lactotrope adenomas, and mammary gland tumors in transgenic female mice producing high levels of human chorionic gonadotropin. Endocrinology 143 4084-4095.

Saitoh M, Ohmichi M, Takahashi K, Kawagoe J, Ohta T, Doshida M, Takahashi T, Igarashi H, Mori-Abe A, Du B et al. 2005 Medroxyprogesterone acetate induces cell proliferation through up-regulation of cyclin D1 expression via phosphatidylinositol 3-kinase/Akt/nuclear factor-kappaB cascade in human breast cancer cells. Endocrinology 146 4917-4925.

Sutherland RL, Prall OW, Watts CK \& Musgrove EA 1998 Estrogen and progestin regulation of cell cycle progression. Journal of Mammary Gland Biology and Neoplasia 3 63-72.

Turgeon JL, Shyamala G \& Waring DW 2001 PR localization and anterior pituitary cell populations in vitro in ovariectomized wild-type and PR-knockout mice. Endocrinology 142 4479-4485.

Walker BE \& Kurth LA 1993 Pituitary tumors in mice exposed prenatally to diethylstilbestrol. Cancer Research 53 1546-1549.

Williams RF, Gordon K, Fung H, Kolm P \& Hodgen GD 1994 Hypothalamo-pituitary effects of RU486: inhibition of progesterone-induced hyperprolactinaemia. Human Reproduction 9 63-68.

Yamasaki L, Bronson R, Williams BO, Dyson NJ, Harlow E \& Jacks T 1998 Loss of E2F-1 reduces tumorigenesis and extends the lifespan of $\mathrm{Rb} 1(+/-)$ mice. Nature Genetics 18 360-364.

Yen SH \& Pan JT 1998 Progesterone advances the diurnal rhythm of tuberoinfundibular dopaminergic neuronal activity and the prolactin surge in ovariectomized, estrogen-primed rats and in intact proestrous rats. Endocrinology 139 1602-1609. 